\title{
THE RESPONSE OF PERFORMANCE TO MERGER STRATEGY IN INDONESIAN BANKING INDUSTRY Analyses on Bank Mandiri, Bank Danamon, and BankPermata
}

\author{
Murti Lestari \\ Faculty of Business, Duta Wacana Christian University \\ Lincolin Arsyad \\ Faculty of Economics and Business, Universitas Gadjah Mada
}

This study analyzes the responses of performances of Bank Mandiri, Bank Danamon, and Bank Permata to merger strategy. This paper harnesses the quantitative approach with structural break analysis method and impulse response function. The plausible findings indicate that the merger of Bank Permata produces a better performance response in comparison to the consolidation of Bank Mandiri and the merger of Bank Danamon. The merger of Bank Permata does not result in performance shocks, and the structural break does not prevail either. On the other hand, the consolidation of Bank Mandiri and the merger of Bank Danamon result in structural breaks, particularly in the spread performance. In order to return to the stable position, the mergers of Bank Mandiri and Bank Danamon require a longer time than does the merger of Bank Permata. This research indicates that for large banks, the mergers and acquisitions (retaining one existing bank) will deliver a better performance response than will the consolidations (no existing bank).

Keywords: impulse response function; merger; structural break 


\section{Introduction}

Merger is one of the strategies to expand a business, including a banking business (Martin 1994:293-295; Garton et al. 2005), because by executing a merger strategy the business could decrease the average costs (Basanco et al. 2004: 73-79) derived from either the economies of scale or the economies of scope. In addition, in the event of shocks, merger could also become a survival strategy. Therefore, in several countries, economic shocks have resulted in a wave of mergers (Koetter 2005; Koskela and Stenbacka 2000; Carletti et al. 2006).

However, in a managerial way, it is not easy to execute mergers, acquisitions, and other corporate actions. There are several technical problems which render mergers unable to yield positive performances for the companies, either in the forms of efficiency, innovation, or profitability. Severalstudies show that in the post-merger period, companies will need an extensive phase for rebuilding process such that the positive performances expected from the merger strategy can be realized. During the rebuilding process, it is common to find merged companies that fail. Fortune magazine observed in 1988 that of the mergers in the United States in the mid of $1980 \mathrm{~s}$, one-half to twothirds had failed. That failure was measured based on the companies' financial performances, meaning that the merged companies showed poorer financial performances compared to those that did not merge or undergo acquisitions. In this study, poorer performances by the banking industry were indicated by a decrease in the thirdparty funds or deposits (Fulmer and Gilkey 1988).

According to Fulmer and Gilkey, there is a fundamental theory in human capital that an employee will psychologically suffer a shock as a result of changes in the organization. Fulmer and Gilkey argue that this human element is rarely considered in the premerger studies so that most merger failures can be traced from human resource problems. A study on 150 mergers and large acquisitions in the United States during the mid 1980s shows that almost 50 percent of senior executives from acquired companies will leave their organizations one year after mergers and 75 percent of them will leave their organizations within three years after the mergers. This finding indicates that in the post-merger period, there are many complicated managerial problems, preventing a merger from immediately producing positive performances. Moreover, mismanagement during the post-merger period can also result in merger failures.

Managerial problems as the negative consequences of merger are not only found in human resources sector; more far-reaching, merger can also create conflicts in the corporate culture (Weber and Camerer 2003). Using an experimental method, Weber and Camerer analyze merger failures associated with corporate culture. Their study shows that decreases in perfor- 
Lestari\&Arsyad - TheResponse ofPerformancetoMergerStrategyinIndonesianBankingIndustry

mances are originated from difficult circumstances resulted from the changes in corporate culture. According to the analysis, the larger the corporations that merge, the larger is the probability of conflicts. Consequently, the probability of performance decreases after mergers will also be greater.

In the case of a transnational merger, post-merger managerial difficulties should be greater. Steensma et al. (2004) conducted a study on an international venture capital company. Their study finds that venture capital companies or transnational mergers are relatively unstable. There are two important factors that cause the unstableness: (1) social exchange and (2) learning perspective. In order to return to a stable position, a unique time line is required in each factor.

Based on this theory, it can be assumed that in general, a specific time line is required so that mergers can result in good performances. Managerially, this period is called the "rebuilding after the merger," and there is no standard for how long it would take. Each merger requires a unique time line, depending on several components such as human resources, culture, and the organizations per se.

In the banking industry, the analysis of the response of performance to consolidation, merger and acquisition strategies have been widely conducted. Research have utilized various approaches which result in a variety of conclusions. One of the studies was conducted by Calomiris and
Pornrojnangkool (2005). The findings show that merger and acquisition do not necessarily improve efficiency, measured by a decrease in average costs. Taking the case of merger and acquisition between Fleet and Boston Bank in New England, Calomiris and Pornrojnangkool conclude that in the post-merger period, credit/loan market in general becomes more monopolistic. However, for small medium enterprises' (SMEs) loans, there is a decrease in interest rate that might be derived from the economies of scale. Nevertheless, if seen from its cost structure, it turns out that merger does not significantly reduce average costs.

Another study which observes banking mergers in Europe (Koeter 2005) demonstrates similar conclusions. Using the stochastic frontier analysis, Koeter concludes that the banking mergers in Europe do not fully improve efficiency. In fact, the difference between the cost efficiency of merged banks and that of non-merged banks is not significantly different. However, when the performance is measured using profitability, merger does increase profits, especially for banks.

Similar studies were also done in Malaysia. Using the method of nonparametric data envelopment analysis, Allen and Boobol-Betchelor (2005) conclude that the wave of banking mergers that occurred in Malaysia during 1996-2002 do not necessarily improve the efficiency of banking in general. In the first year of mergers, banks that merge have suffered from decreasing efficiency, and for subsequent 
Gadjah Mada InternationalJournal ofBusiness, May-August2010, Vol.12,No.2

years have shown no clear pattern of performance responses toward the mergers.

For the case of Indonesia, there are several studies with different approaches. One study was conducted by Mardanugraha (2005). Using the parametric cost approach to analyze the case of Bank Mandiri merger, Mardanugraha concludes that the bank merger in Indonesia has certainly decreased the efficiency level although it has been able to increase the stability. Another study was conducted by Samosir (2003), who also researched the merger of Bank Mandiri. Utilizing the financial ratio approach, Samosir's conclusion is not very much different from Mardanugraha's, i.e., the merger of Bank Mandiri has indeed reduced its financial efficiency and performance.

Predicated upon the aforementioned discussion, it seems that mergers do not immediately result in good performances. Rather, an extensive process is required. Mergers can even fail because of managerial process. This study purports to analyze the response of performance to merger strategy in Indonesian banking industry. The structure of this paper is organized as follows. Section 1 introduces the ideas, section 2 reviews the banks being studied, sections 3 and 4 are the methodology and analysis, and section 5 concludes.
Overviews of Bank Mandiri, Bank Danamon, and Bank Permata Mergers

In 1997-1998, the Indonesian banking industry experienced a crisis which was started by the closures of 16 private commercial banks. This phenomenon made people panic, and triggered an economic crisis. Afterwards, the government commenced on a new stage in developing Indonesian banking industry by taking several steps to recapitalize the banking industry. Those steps include: (1) providing liquidity assistance; (2) forming an Indonesian Bank Restructuring Agency/Badan Penyehatan Perbankan Indonesia (BPPN), one of whose tasks is to take over non-performing loans (NPL); and (3) performing mergers of several banks. The main objective of these policies is to build a strong framework for the banking industry such that the industry can act as a powerful development tool.

With the recapitalization programs, the dynamics of Indonesian banking industry in the post-crisis period (in the end of 1990s and beginning of 2000s) is increasingly characterized by banks' mergers, consolidations, or acquisitions. According to the industry terminology, this phenomenon is deemed a wave of mergers, considering the numbers of mergers, consolidations, and acquisi- 
Lestari\& Arsyad - TheResponse ofPerformancetoMerger StrategyinIndonesianBankingIndustry

tions executed, as one of the efforts to recapitalize the damaged banking industry caused by the 1997-1998 economic crisis. In this period, there were three phenomenal bank mergers, i.e., the merger of Bank Mandiri, the merger of Bank Danamon, and the merger of Bank Permata.

Bank Mandiri is a bank resulting from the merger of four state banks, i.e., Bank Dagang Negara, Bank Bumi Daya, Bank Pembangunan Indonesia, and Bank Ekspor Impor. Based on the Government Regulation (Peraturan Pemerintah) (PP) No. 28/1999, this kind of incorporation is called a consolidation, where the four banks were dissolved and a new bank was formed. The merger process of Bank Mandiri began in October 1998 as a part of banking restructuring programs. Although the process had started since 1998, Bank Mandiri was not operating until July 1999. The merger of Bank Mandiri is an interesting merger since it is a merger of four established banks.

Two other phenomenal mergers after the economic crisis were the merger of Bank Danamon and the merger of Bank Permata. Bank Danamon emerges a result of the merger of 11 banks with two stages of merger in which Bank Danamon is retained as the existing bank. In the first stage of merger which was carried out in 1999, Bank Danamon acquired Bank PDFCI. In the second stage of merger in 2000, eight banks were merged, i.e., Bank Tiara, Bank
Duta, Bank Rama, Bank Tamara, Bank Nusa Nasional, Bank Pos Nusantara, Bank Jaya Internasional, and Bank Rasyid Salim. Thus, the current Bank Danamon is the incorporation of 11 banks, which is Danamon plus PDFCI and plus other eight banks in the second stage of merger. Compared to other mergers from the organizational side, the merger of Bank Danamon is a large merger although the individual banks that merged are relatively small.

Quite different from Banks Mandiri and Danamon, the merger of Bank Permata is a merger of relatively small banks, i.e., Bank Bali, Bank Universal, Bank Prima Express, Bank Artamedia, and Bank Patriot. In the merger process, Bank Bali was appointed as the platform bank since of the five banks, Bank Bali was relatively large and existent. Then, the four banks were merged into the platform bank, and the name of the five merged banks was changed to be Bank Permata. This merger was performed as an implementation of the government decision in September 2001. However, the actual merger was not carried out until May 2002.

Those three bank mergers are mergers based on the government policy. All banks which merged were takeover banks as they failed during the crisis. Therefore, those mergers are basically not a business strategy performed voluntarily, but are arranged by the government to enhance the structure of the banking industry. 


\section{Methodology}

\section{Impulse Response Function Method}

In order to measure the response of performance to merger strategy observed in the consolidation of Bank Mandiri, the merger of Bank Mandiri, and the merger of Bank Permata, this study employs an econometric method by estimating the impulse response function (IRF) model. The IRF approach is chosen because this method delivers better results in measuring responses compared to other methods such as Taylor or Maclaurin series (Cerra and Saxena 2008).

To estimate the IRF, this study uses the indirect vector autoregressive (VAR). IRF traces the responses of dependent variable in the VAR system to shocks from the error term in that system(Gujarati2003:853-854; Enders 2004: 272-277). The models of structural VAR estimated in this study are as follows:

$$
\begin{aligned}
Y_{t}+\alpha_{12} X_{t-1}= & \alpha_{10}+\sum_{i=1}^{k} \beta_{i} Y_{t-1}+ \\
& \sum_{i=1}^{k} \gamma_{i} X_{t-1}+\varepsilon_{1 t} \ldots \ldots . .
\end{aligned}
$$

$$
\begin{aligned}
\alpha_{21} Y_{t}+X_{t-1}= & \alpha_{2 o}+\sum_{i=1}^{k} \beta_{i} Y_{t-1}+ \\
& \sum_{i=1}^{k} \gamma_{i} X_{t-1}+\varepsilon_{2 t} \ldots \ldots .
\end{aligned}
$$

with:

$Y_{t}$ : banks' performances

$\mathrm{X}_{\mathrm{t}}$ : dummy; 1 if post-merger (acquisition), 0 if pre-merger (acquisition)

$\varepsilon_{\mathrm{t}}$ : error term

Since $X_{t}$ is a dummy, the estimation in the SVAR models uses the probit model as the dependent variable as described in the following equations (3) and (4).

From the SVAR models, in order to detect the response of performance to merger and acquisition strategies, the following IRF models are estimated:

$$
\begin{array}{r}
Y_{t}=c_{o}+\sum_{j=1}^{k}\left(c_{1 j} \varepsilon_{1 t-j}+c_{2 j} \varepsilon_{2 t-j}\right)+e_{1 t} \ldots(3) \\
\operatorname{Pr}\left(X_{t}=1\right)=F\left[d_{o}+\sum_{j=1}^{k}\left(d_{1 j} \varepsilon_{1 t-j}+\right.\right. \\
\left.\left.d_{2 j} \varepsilon_{2 t-j}\right)+e_{2 t}\right) \ldots \ldots \ldots .(4)
\end{array}
$$

with:

$Y_{t}$ : banks' performances

$\mathrm{X}_{\mathrm{t}}: 1$ if post-merger (acquisition),

0 if pre-merger (acquisition)

$\varepsilon_{\mathrm{t}}$ : errors from models (1) and (2)

According to theory, the association between merger and performance is a one-way relation, i.e., performance does not affect merger; hence, $\alpha_{21}=0$. For that reason: 
Lestari\&Arsyad-TheResponse ofPerformancetoMergerStrategyinIndonesian BankingIndustry

$\varepsilon_{2 \mathrm{t}}=\mathrm{e}_{2 \mathrm{t}}$

$\varepsilon_{1 \mathrm{t}}=\mathrm{e}_{1 \mathrm{t}}+\alpha_{12} \mathrm{e}_{2}$

The IRF model developed in this study estimates the response of performance to merger and acquisition strategies. For this objective, several measurements of performances are employed. Theoretically, the performance measurement of a company (an industry) can be analyzed using several variables (Martin 1994; 14-38). First, the number of produced outputs. Larger outputs mean the company has better performance since it indicates efficiency from the economies of scale. Second, the spread between output selling price and input buying price. Lower spread of the prices means better performance. Third, the average costs. Lower average costs indicate a higher efficiency which means better performance. Fourth, profit. In a perfectly competitive market, higher profit depicts efficiency in cost minimization so that higher profit means better performance.

On the basis of the theory, this study uses Martin's concepts and Dymski's approaches (2002) to measuring performance by using these measurements: (1) the size of disbursed credits as the measurement of output performance; (2) the spread between time deposit rate and saving deposit rate as the measurement of input and output price deviation; (3) OEOI, the ratio between the operational expenses and the operational income as the measurement of average costs; and (4) profit before taxes. For the merger variable, this study uses a dummy variable which takes the value of 1 if it is the post-merger or acquisition period, and 0 otherwise.

\section{Data Examination and the Analysis of Structural Break}

To employ the estimation, the period taken is from quarter 1 of 1993 to quarter 1 of 2009. This period selection is based on the objective of this study, which is to observe the effects of merger on performance. Three important mergers in Indonesia prevailed in the period: the merger of Bank Mandiri in 1999, the merger of Bank Danamon in 2000, and the merger of Bank Permata in 2002. Therefore, the period taken must be before 1999 and after 2002.

Based on the sampling period and the estimation method, this study uses time series data. Statistically, time series data include four components, i.e., trend (T), seasonal (S), cyclical (C), and irregular (I). With these components, the time series data often have an unstable pattern, so the average value (mean) and variance are not constant. In econometrics, the data to be estimated must meet the requirements of constant mean and variance, i.e., $E(Y t)=\mu$, and $\operatorname{Var}(Y)=E\left(Y_{t}\right.$ $\mu)^{2}=\sigma^{2}$. With these requirements, an estimation using time series data must satisfy the basic principle that the data must be stationary or do not contain unit roots. The consequence of not meeting this principle is the emergence 
of a spurious or chaotic regression, and the violation of classical assumptions. Therefore, the initial step of the estimation process in this study is to test the data stationarity.

The testing of data stationarity has developed for a long time. DickeyFuller approach is the most popular approach. Dickey-Fuller unit root test is used on the condition of non-structural break. This test consists ofDickeyFuller test (DF Test) and Augmented Dickey-Fuller test (ADF test). In their developments, the DF and ADF tests are considered too simple, and can lead to a bias (wrong) statistical conclusion because they do not accommodate the structural changes in variables, whereas, in fact, most of all economic variables (especially macro variables) contain structural break elements. Structural changes, statistically, occur when a stationary data series experiences shifting in its average value (mean) permanently(Enders 2004: 200202).

On the basis of a widely occurred structural break, unit roots testing which is able to capture structural changes is developed. One test with this method was developed by Perron and Vogelsang (1992) and Perron (1997), which is widely known as the PhillipsPerron test or PP test (Enders 2004: 207). The null hypothesis of the PP test is the data contain unit roots or are not stationary, and its alternative hypothesis is the data do not contain unit roots or are stationary.
Another stationarity test which is able to capture the structural changes is a test developed by Kwiatkowski, Phillips, Schmidt, and Shin or knownby the KPSS test. The null hypothesis of the KPSS test is the data do not contain unit roots or are stationary, and its alternative hypothesis is the data contain unit roots or are not stationary. The Kwiatkowski model (Kwiatkowski, et al.: 1992) is basically a refinement of the DF and PP method. According to Kwiatkowski, the methods that make an initial assumption (null hypothesis) of data contain unit roots are actually based on a very weak argument. Therefore, he argues that if the null hypothesis of the DF or PP test is confirmed, it must be supplemented by the rejection of the null hypothesis in the KPSS test, which states that the data are stationary.

The test of stationarity was then improved by Zivot and Andrews in their study on the impacts of oil price shocks on the U.S. economy (Zivot and Andrews 1992). In their paper, they criticize the unit roots test with PP and KPSS approaches since the tests could produce incorrect statistical conclusions, especially when the variables contain structural changes.

The study of Zivot and Andrews actually complements and enhances the study of PP and KPSS. In his research, Perron is rather a priori, because he does not include variables that capture informational of structural changes specifically. In his analysis, 
Lestari\&Arsyad-TheResponse ofPerformancetoMergerStrategyinIndonesian BankingIndustry

Perron only reveals that the structural changes in data are gathered from previous information that has happened. According to Zivot and Andrews, this is a weakness that must be addressed.

To complement Perron's analysis, Zivot and Andrews include three variables that can capture the structural changes: (1) dummy mean, (2) dummy trend, and (3) mean or dummy regime. In their model, Zivot and Andrews label the variables as "shift in mean," "shift in trend," and "shift in regime." The equations estimated to capture the structural changes are as follows.

1. Shift in Mean (Structural Changes in Intercept)

$$
\begin{aligned}
\Delta Y_{t}= & \hat{\alpha}+\hat{\theta} Y_{t-1}+\hat{\delta} t+ \\
& \hat{\phi} \operatorname{DU}_{t}\left(\hat{\lambda}_{t}\right)+\hat{\varepsilon}_{1 t}
\end{aligned}
$$

in which $D U_{t}$ is a dummy mean variable which serves to capture the structural changes in intercept (á).

2. Shift in Trend (Structural Changes in Trend)

$$
\begin{array}{r}
\Delta \mathrm{Y}_{\mathrm{t}}=\hat{\alpha}+\hat{\theta} \mathrm{Y}_{\mathrm{t}-1}+\hat{\delta} \mathrm{t}+ \\
\hat{\psi} \mathrm{DT}_{\mathrm{t}}\left(\hat{\lambda}_{\mathrm{t}}\right)+\hat{\varepsilon}_{2 \mathrm{t}} \cdots
\end{array}
$$

in which $D T_{t}$ is a dummy trend variable which serves to capture the structural changes in trend $(\mathrm{t})$.

3. Shift in Regime(Structural Changes in Intercept and Trend)

$$
\begin{array}{r}
\Delta \mathrm{Y}_{\mathrm{t}}=\hat{\alpha}+\hat{\theta} \mathrm{Y}_{\mathrm{t}-1}+\hat{\delta} \mathrm{t}+\hat{\phi} \mathrm{DU}_{\mathrm{t}}+ \\
\\
\hat{\psi} \mathrm{DT}_{\mathrm{t}}\left(\hat{\lambda}_{\mathrm{t}}\right)+\hat{\varepsilon}_{3 \mathrm{t}} \ldots \ldots \ldots \ldots . . .
\end{array}
$$

in which $D U_{t}$ and $D T_{t}$ are dummy regime variables which serve the structural changes in intercept $(\alpha)$ and trend $(\mathrm{t})$.

With this refinement, Zivot and Andrews model is able to detect whether in a certain period of time one variable experiences structural breaks without information of previous existing structural breaks.

Not only is Zivot and Andrews approach able to test unit roots, but it also could detect when a variable experiences structural changes. Thus, an extensive interpretation as to whether a shock on a variable can lead to a significant shock can be made. This kind of interpretation is very important economically, considering that in time series data, the influences of irregular elements have been less able to be examined, or even to be detected.

Although Zivot and Andrews approach is the most advanced unit roots test, this study is focused on the DF, PP, and KPSS approaches to examining the data stationarity. This is based on the consideration of the limitation of program tools. However, Zivot and Andrews approach is still performed, not to test the data stationarity, but to observe whether there are structural changes (structural break) in bank performance as a result of merger. This 
Gadjah Mada InternationalJournal ofBusiness, May-August2010, Vol.12,No.2

analysis is performed to complement the IRF analysis on the mergers of Bank Mandiri, Bank Danamon, and Bank Permata. By doing this analysis, the authors hope that this study can contribute a more comprehensive interpretation of merger strategy in Indonesian banking industry.

\section{Results and Analysis}

The data stationarity testings using the DF, PP, and KPSS approaches find that the data of performance variables for the three banks used in the estimations are generally stationary in level.

\section{Structural Break Analysis}

The observation of structural breaks with the ZA test for each variable in each bank can be seen in the Table1.

The Table 1 shows that there was a structural break from quarter 4 of 1997 to quarter 4 of 1998 in the time series data of Bank Mandiri's loans. If associated with events occurring at that time, it may be concluded that the 1997-1998 crisis has caused a structural break to the credit/loan variable of Bank Mandiri. Meanwhile, the merger phenomenon in July 1999 did not cause a structural break to the loan variable of Bank Mandiri. Two other variables did not show any sign of structural break during the observation period (Q1 1993 untilQ1 2009), implying that the 1997-1998 crisis and the merger phenomenon did not lead to a structural break in both variables. On the other hand, the spread variable experienced several structural breaks from Q4 of 1999 to Q1 of 2002. It can be concluded that the structural breaks are the response to the merger phenomenon that occurred in July 1999 or Q3 of 1999. This means that the merger phenomenon can cause structural breaks to the performance variables of Bank Mandiri, particularly the spread variable.

Table 1. Structural Break Tests on Performance Variables of Bank Mandiri

\begin{tabular}{|c|c|c|c|}
\hline \multirow[b]{2}{*}{ Variable } & \multicolumn{3}{|c|}{ StructuralBreak } \\
\hline & Mean & Trend & Regime \\
\hline Loan & Year of 1998Q4 & - & $\begin{array}{l}\text { Year of 1997 Q4 } \\
\text { Year of 1998 Q4 }\end{array}$ \\
\hline OEOI & - & - & - \\
\hline Spread & Year of 1999 Q4 to year of 2000 Q1 & - & $\begin{array}{l}\text { Year of } 1999 \text { Q1 to } 2000 \text { Q2 } \\
\text { Year of } 2001 \text { Q1 } \\
\text { Year of } 2002 \text { Q4 }\end{array}$ \\
\hline Profit & - & - & - \\
\hline
\end{tabular}

Source: Estimation results 
Lestari\&Arsyad-TheResponse ofPerformancetoMergerStrategyinIndonesian BankingIndustry

Similar to Bank Mandiri, Bank Danamon's performance variables also experienced some structural breaks. Details of the structural breaks periods experienced by Bank Danamon during the observation period can be seen in Table 2.

Table 2 shows that the credit/loan variable experienced a structural break from quarter 3 of 1997 to quarter 1 of 1998. Meanwhile, two other variables, i.e., OEOI and profit did not show any sign of structural breaks during the observation period. The spread vari- able experienced a structural break from quarter 1 to quarter 3 of 2000 . This indicates, similar to the case of Bank Mandiri, that the spread variable of Bank Danamon experiences a structural break as a response to the merger event that occurred in 2000, while three other variables do not respond the merger event. From the data observation, the structural breaks to the loan variable are more a response to the crisis phenomenon than to the merger phenomenon.

Table 2. Structural Break Tests on Performance Variables of Bank Danamon

\begin{tabular}{|c|c|c|c|}
\hline \multirow[b]{2}{*}{ Variable } & \multicolumn{3}{|c|}{ StructuralBreak } \\
\hline & Mean & Trend & Regime \\
\hline Loan & $\begin{array}{l}\text { Year of 1997 Q3 to year of } \\
\text { 1998Q1 }\end{array}$ & - & $\begin{array}{l}\text { Year of 1997 Q3 to year of } \\
\text { 1998Q1 }\end{array}$ \\
\hline OEOI & - & - & - \\
\hline Spread & Year of 2000 Q1 to Q2 & - & Year of 2000 Q2 to Q3 \\
\hline Profit & - & - & - \\
\hline
\end{tabular}

Source: estimation result

Table 3: Structural Break Tests on Performance Variables of Bank Permata

\begin{tabular}{|c|c|c|c|}
\hline \multirow[b]{2}{*}{ Variable } & \multicolumn{3}{|c|}{ StructuralBreak } \\
\hline & Mean & Trend & Regime \\
\hline Loan & $\begin{array}{l}\text { Year of 1997 Q4 to } \\
\text { year of } 1998 \text { Q1 }\end{array}$ & $\begin{array}{l}\text { Year of } 1997 \text { Q4 to } \\
\text { year of } 1998 \text { Q1 }\end{array}$ & $\begin{array}{l}\text { Year of } 1997 \text { Q4 to } \\
\text { year of } 1998 \text { Q1 }\end{array}$ \\
\hline OEOI & - & - & - \\
\hline Spread & - & - & $\begin{array}{l}\text { Year of 1998 Q1 to Q3; } \\
\text { Year of 2001 Q4 }\end{array}$ \\
\hline Profit & - & - & - \\
\hline
\end{tabular}

Source: estimation results 
Gadjah Mada InternationalJournal of Business, May-August 2010, Vol. 12,No.2

Compared to the cases of Bank Mandiri and Bank Danamon, the structural breaks prevalent in Bank Permata show a quite different pattern, especially when associated with the merger event of Bank Permata in early 2002. The detailed observations of structural breaks in Bank Permata can be seen in Table 3.

Table 3 shows that the credit/loan variable of Bank Permata experienced structural breaks in the period of late 1997 to early 1998. Meanwhile, the spread variable experienced structural breaks from early 1997 to Q3 of 1998. These structural breaks reappeared in the end of 2001. The two other variables, i.e., OEOI and profit, did not show any sign of structural breaks in the period of observation. The findings of structural breaks tests indicate that the performance variables of Bank Permata are not responsive to the merger event of the bank in early 2002.
This may indicate that Bank Permata is more sensitive to the shock of the 1997-1998 crisis than to the merger phenomenon in the 2000s.

\section{Impulse Response Function (IRF) Analysis}

The IRF analysis is basically intended to observe the response of a variable when a shock occurs. In this study, merger is considered a shock to a bank, and hence, performance variables will provide responses to the merger shock. The IRF diagrams in the subsequent part illustrate the responses of performance variables when a merger shock in the size of one standard deviation occurs.

\section{IRF Estimation for Bank Mandiri} a. IRF of Credit Performance. IRF estimation of the credit/loan performance is shown in Figure 1.

\section{Figure 1. Response of Bank Mandiri's Credit Performance to Merger Shock}

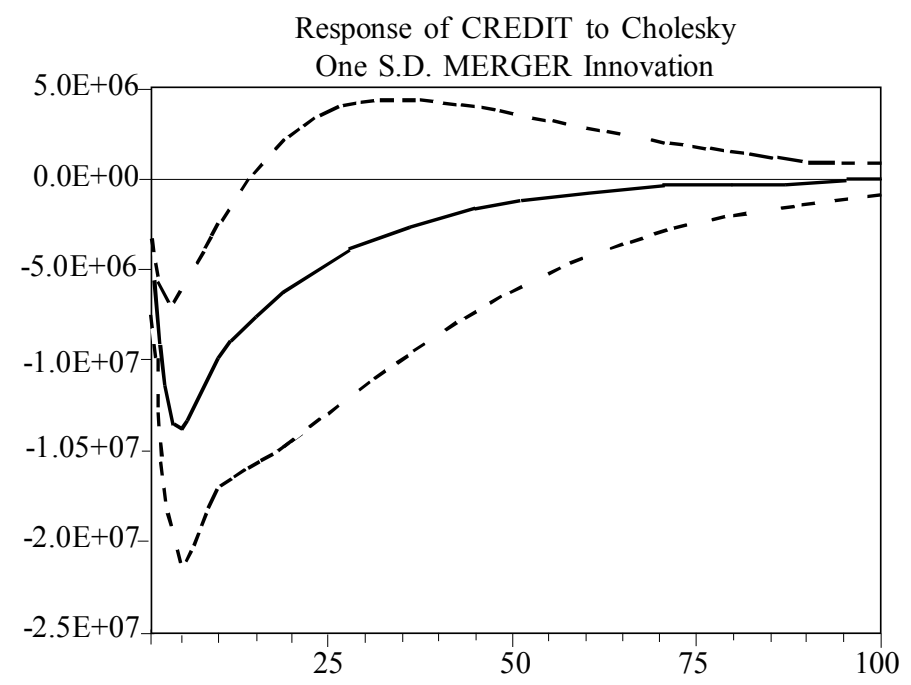


Lestari\&Arsyad-TheResponse ofPerformancetoMergerStrategyinIndonesian BankingIndustry

Figure 1 depicts that if there is one standard deviation in merger shock, Bank Mandiri's credit performance experiences a decrease in the initial period. After five periods (five quarters), credit shows a turning point and increases. It can also be seen from Figure 1 that as a result of one standard deviation in merger shock, Bank Mandiri needs an extensive phase of approximately 80 periods or 20 years to return to its stable condition as before the merger.

When associated with the characteristics of the banks merged into Bank Mandiri, i.e., Bank Dagang Negara, Bank Pembangunan Indonesia, Bank Ekspor Impor, and Bank Bumi Daya, the merger of Bank Mandiri is a merger of existed banks with quite significant strengths. Therefore, if there is a merger shock, it will take an extensive time to stabilize. This is consistent with the organizational theories that the merger of several large corporations requires a longer time to rebuild after the merger due to significant adjustment issues of organizational culture and human resources compared to the merger of small companies.

b. IRF of OEOI Performance. Somewhat different from the credit performance, the OEOI variable in response to the merger shock requires less time to return to normal. The IRF estimation results of Bank Mandiri's OEOI performance response to one standard deviation in merger shock can be seen in Figure 2. Figure 2 shows that in the event of a one standard deviation in merger shock, OEOI increases in the initial period, which means there is inefficiency, and after the merger continues for about two quarters (half a year) the increase reaches its peak, and then the OEOI decreases.

Figure 2.Response of Bank Mandiri's OEOI Performance to Merger Shock

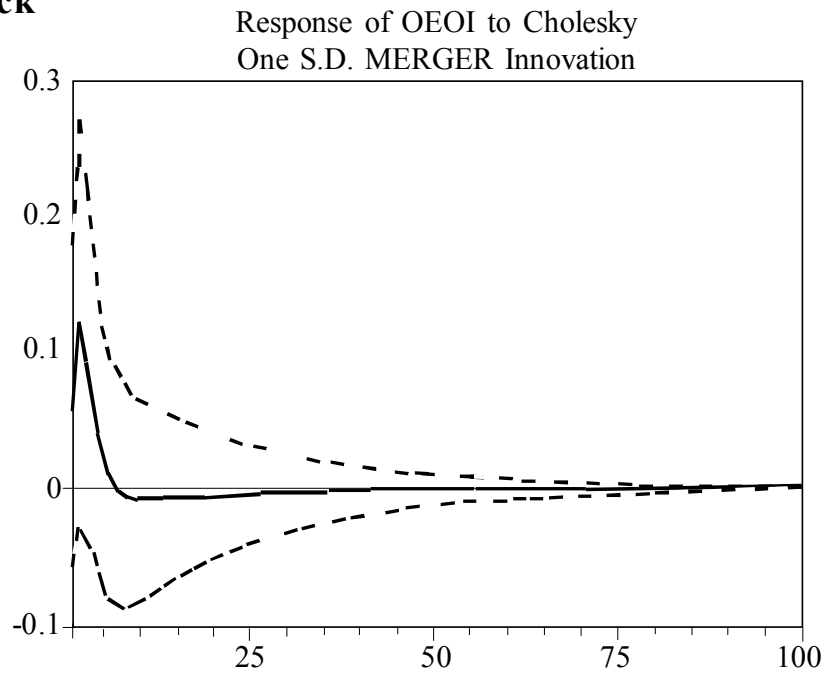


The decrease continues and then reaches a stable condition after the merger runs for about 26 quarters or six-and-a-half years. From this observation, conclusion can be drawn that in response to the merger, the OEOI's performance reaches the stable point faster than does the credit variable.

If OEOI is used as an indicator of bank efficiency, the response of Bank Mandiri's OEOI performance to the merger provides a quite unique efficiency indicator. During the postmerger period, Bank Mandiri shows a worsening efficiency response; the OEOI strengthens (a positive reaction) then declines, and after six quarters (one-and-a-half years) of merger, the OEOI shows a negative reaction. This means that one-and-a-half years after the merger, Bank Mandiri's OEOI undergoes an increase in efficiency performance due to the negative re- sponse of OEOI. OEOI reaches a stable condition faster than does credit/ loan, indicating that the internal health performance of Bank Mandiri is relatively unaffected by the merger compared to its external performance in the form of credits.

c. IRF of Spread Performance. Subsequently, it is found that the response of spread performance to the merger of Bank Mandiri corresponds with that of credit/loan variable. The response of spread performance variable to the merger shock can be seen in Figure 3 in which the reaction of spread to one standard deviation in merger shock is shown. The spread increases in the beginning, and it reaches its climax after 10 quarters (two-and-a-half years). It then decreases and reaches a stable position after 75 quarters or about 18 years. Unlike the OEOI, the reaction of spread is always positive. If

Figure 3.Response of Bank Mandiri's Spread Performance to Merger Shock

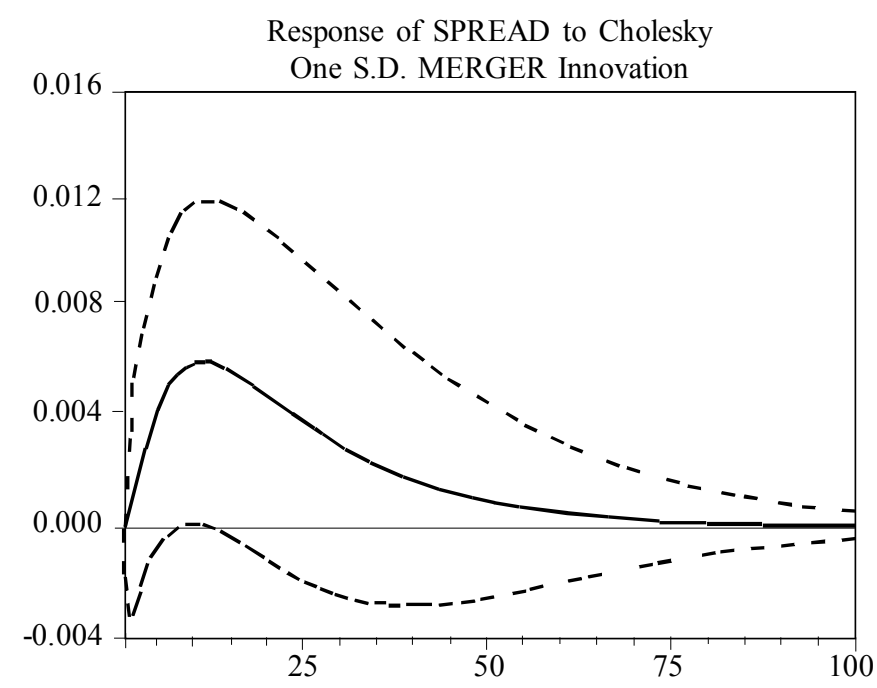


Lestari\&Arsyad-TheResponse ofPerformancetoMergerStrategyinIndonesian BankingIndustry

spread is used as an indicator of efficiency, then the merger of Bank Mandiri decreases the efficiency until it reaches a stable condition.

This fact is very different from the case of OEOI performance, but relatively similar to the credit/loan performance. In the post-merger period, in order to achieve a stable condition, the credit variable will take approximately 20 years but is not responsive with respect to spread reduction. Under these circumstances, it can be concluded that if there is one standard deviation in merger shock, the credit and spread variables of Bank Mandiri will experience negative reactions until they achieve a stable condition.

d. IRF of Profit Performance. The response of Bank Mandiri's profit performance to merger shock shows a similar pattern when compared with
OEOI variable. Figure 4 below shows the reaction of Bank Mandiri's profit performance to one standard deviation in merger shock. The profit variable reacts negatively in the beginning to the merger shock. However, unlike credit/ loan variable, this decline only lasts shortly. After two quarters (half a year), the decrease reaches its bottom and the profit variable begins increasing, and it achieves a positive point after the merger runs for six quarters.

Furthermore, the profit movement is always positive and achieves a stable condition after 60 quarters (15 years). Compared to the credit and spread variables, the profit variable in response to the merger shock only requires a relatively short time to reach a stable condition.

If profit and OEOI are used as efficiency indicators of a bank's inter-

\section{Figure 4. Response of Bank Mandiri's Profit Performance to Merger Shock}

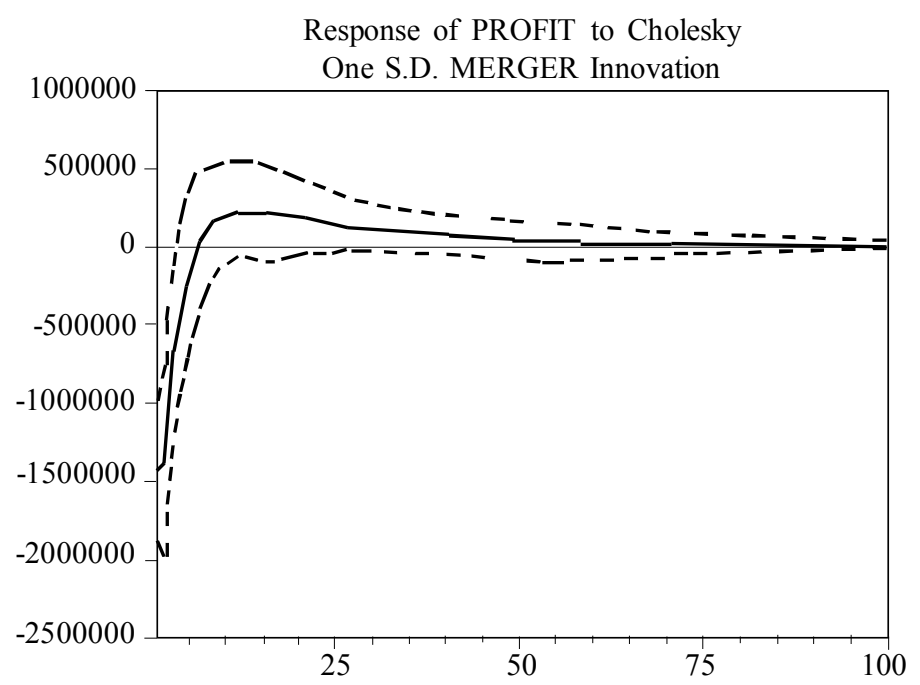


nal health, then the similarity of profit's and OEOI's responses to the merger shock implies that the merger of Bank Mandiri is responded positively by the bank's internal health. Meanwhile, if credit and spread are used as the indicators of external performance, the merger of Bank Mandiri is responded negatively until the bank reaches its stability in the post-merger period.

\section{Results of IRF Estimation for Bank Danamon}

a. IRF of Credit Performance. The response of Bank Danamon's performance to merger shock is relatively equivalent to that of Bank Mandiri. The pattern can be seen in Figure 5, which shows that if there is one standard deviation in merger shock, Bank Danamon's credit/loan performance will impoverish or have a negative value in the initial period. After 10 quarters (two-and-a-half years), the decline reaches its pit, and it then starts improving. Nevertheless, this increase never reaches a positive level, and it reaches the stable condition only after the merger runs for 76 quarters (19 years).

b. IRF of OEOI Performance. Different from the credit/loan performance, the merger shock to Bank Danamon is followed by a more dynamic response of OEOI performance. Details of the response of OEOI performance to one standard deviation in merger shock are described in Figure 6 , showing that in the beginning, the OEOI increases and reaches its peak after the merger runs for five quarters. Afterwards, the OEOI declines and reaches its bottom 12 quarters after the merger. OEOI eventually reaches its stable condition after 40 quarters (10 years) of merger.

Figure 5. Response of Bank Danamon's Credit Performance to Merger Shock

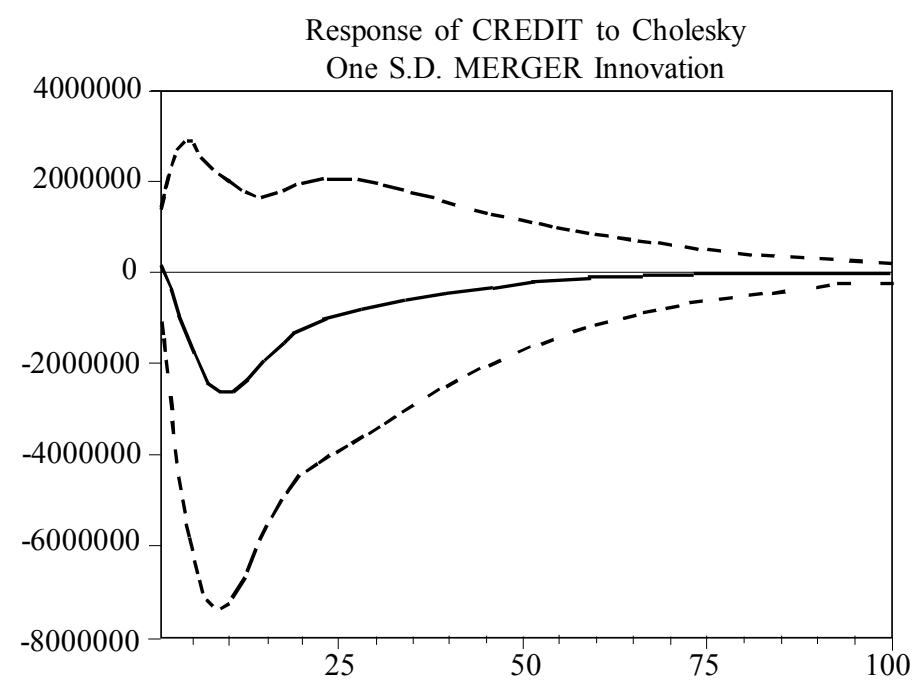


Lestari\& Arsyad - TheResponse ofPerformancetoMerger StrategyinIndonesianBankingIndustry

\section{Figure 6. Response of Bank Danamon's OEOI Performance to Merger Shock}

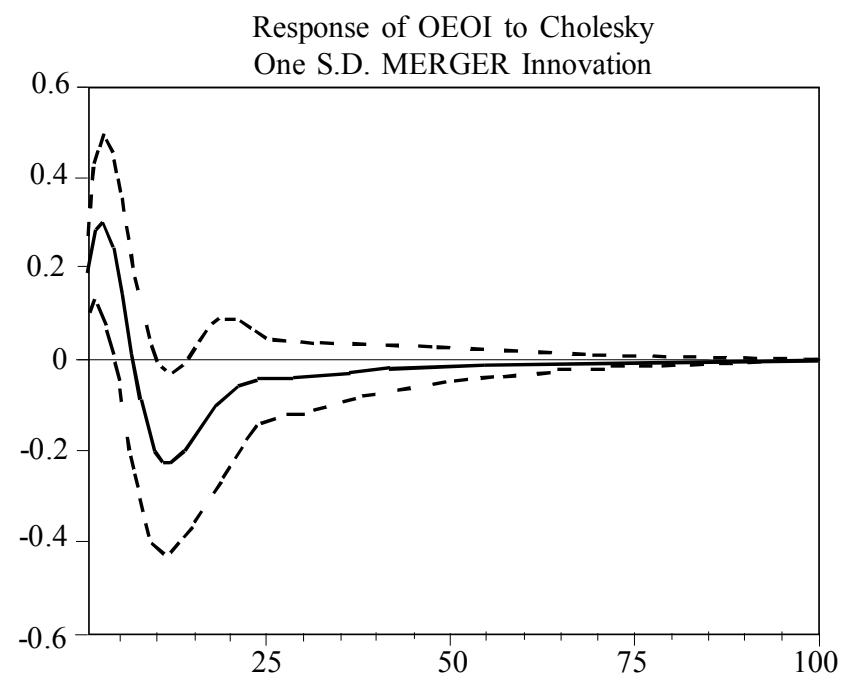

The pattern of OEOI indicates that by using the OEOI indicator, the merger of Bank Danamon delivers a faster efficiency reaction compared to using the credit indicator. If OEOI is harnessed as an indicator of bank efficiency and internal bank health, then the merger of Bank Danamon yields a good internal efficiency since OEOI already shows a negative response to the merger shock within the period of six quarters (one-and-a-half years).

c. IRF of Spread Performance. Similar to the OEOI variable, the response of spread performance to the shock also has an expectedly good pattern. Figure 7 shows the response of spread performance variable to one standard deviation in merger shock. In the beginning, the response of spread to merger shock is positive (inefficient), but after two quarters (half a year) the response sees a turning point. It never reaches a negative level after arriving at the stable condition when the merger has run for 50 quarters (12.5 years).

d. IRF of Profit. Slightly different from the case of Bank Mandiri, the profit performance of Bank Danamon never responds negatively to themerger shock. Graphically, the response of profit performance to the merger shock for Bank Danamon can be seen in Figure 8.

Since the beginning period, the response of profit has always been positive. After five quarters, the response reaches the climax and then the stable condition, which is after the merger runs for 80 quarters (20 years). Compared to that of Bank Mandiri, this pattern is quite different as Bank Danamon's profit never produces a negative reaction such as found in Bank Mandiri. 
Gadjah Mada InternationalJournal of Business, May-August2010, Vol.12,No.2

Figure 7. IRF of Bank Danamon's Spread Performance to Merger Shock

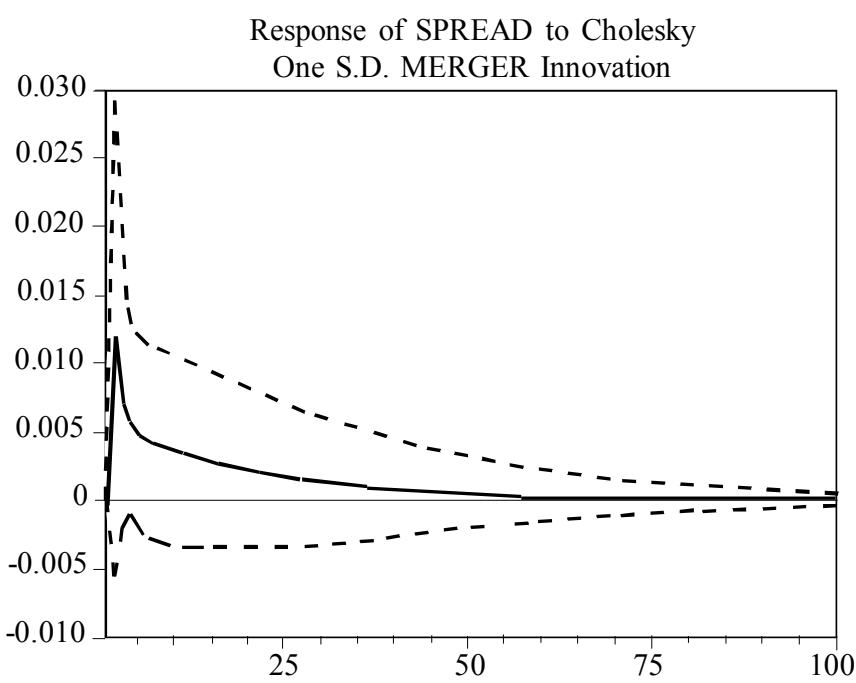

Figure 8. IRF of Bank Danamon's Profit Performance to Merger Shock

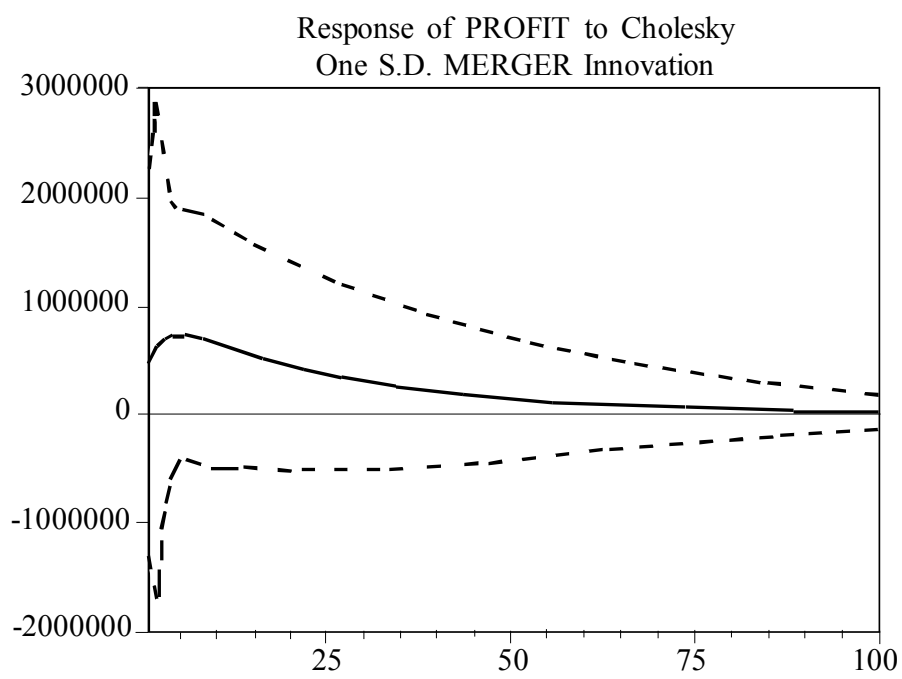

IRF Estimation Results for Bank Permata

a. IRF of Credit Performance. The detailed response of creditperformance to merger shock for Bank Permata is depicted in Figure 9.
The response of Bank Permata's credit performance undergoes a different pattern from those of Bank Mandiri and Bank Danamon. If Bank Mandiri and Bank Danamon respond negatively with respect to their credit 
Lestari\&Arsyad-TheResponse ofPerformancetoMergerStrategyinIndonesianBankingIndustry

performances until the stable condition, the negative response of Bank Permata's credit performance is only temporary, only for eight quarters (two years). After two years, the credit performance delivers a positive response until reaching the stable condition in less than 15 years.
This pattern of credit performance is quite interesting since Bank Permata is a resulting merger of relatively small banks compared to Bank Mandiri and Bank Danamon. This pattern indicates that the merger of small banks could deliver positive credit performancerelative to the merger of large banks. If

Figure 9. IRF of Bank Permata's Credit Performance to Merger Shock

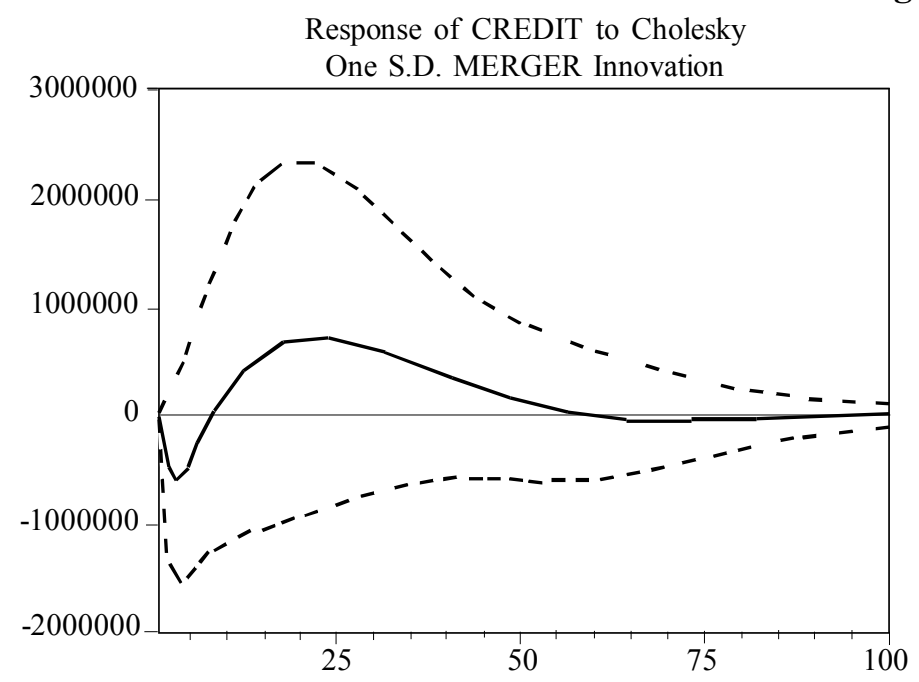

Figure 10. IRF of Bank Permata's OEOI Performance to Merger Shock

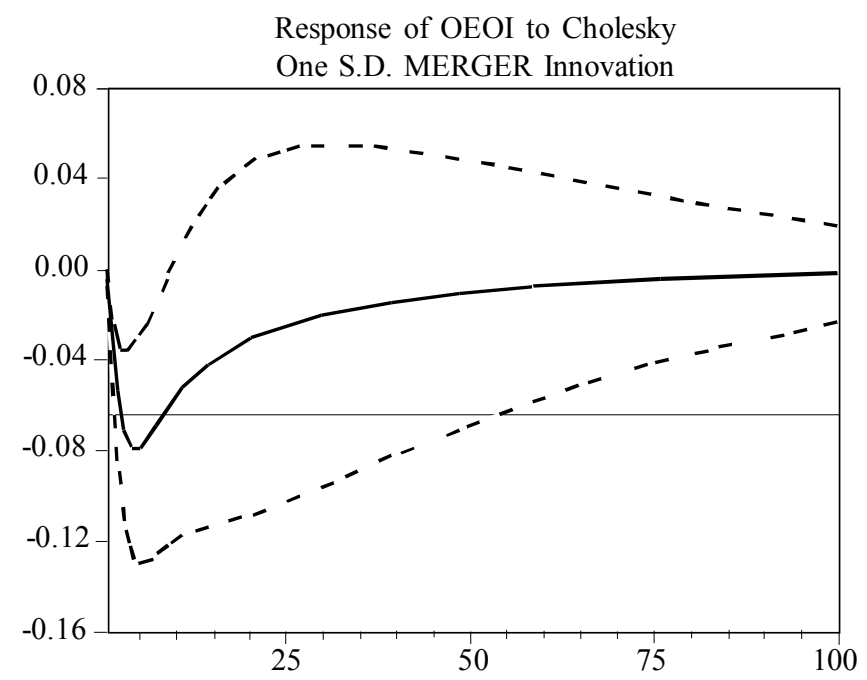


discussed within the managerial theory perspective, this is very possible as the merger of small corporations in general leads to less profound organizational conflicts so that the merger will deliver faster positive performance. In the case of Bank Permata, it seems that the consolidation after merger runs so fast that the bank management can immediately increase its credits/loans aggressively.

b. IRF of OEOI Performance. In line with the credit performance, the response of Bank Permata's OEOI performance to the merger shock is negative. As seen in Figure 10, the response of OEOI performance to one standard deviation in merger shock is always negative until it reaches the stable condition. This indicates that the merger of Bank Permata is reacted by a decrease in OEOI performance or an efficient reaction. The stable condition is attained within a relatively long pe- riod of time, i.e., 20 years. Since the OEOI's response leads to an indication of efficiency, the long duration is probably caused by the development of managerial innovations that improve efficiency.

c. IRF of Spread Performance. It seems that the response of spread performance to merger shock has the same pattern as that of OEOI performance. Figure 11 shows the response of spread performance to one standard deviation in merger shock for Bank Permata. As can be seen in the figure, the spread performance never reaches a positive level until it obtains the stable condition. In other words, an increase in spread never happens in responding the merger, implying that the merger of Bank Permata has created spread efficiency. Somewhat different from the OEOI, the spread performance only requires a relatively short time, which is more than 12.5 years, to reach the

Figure 11. IRF of Bank Permata's Spread Performance to Merger Shock

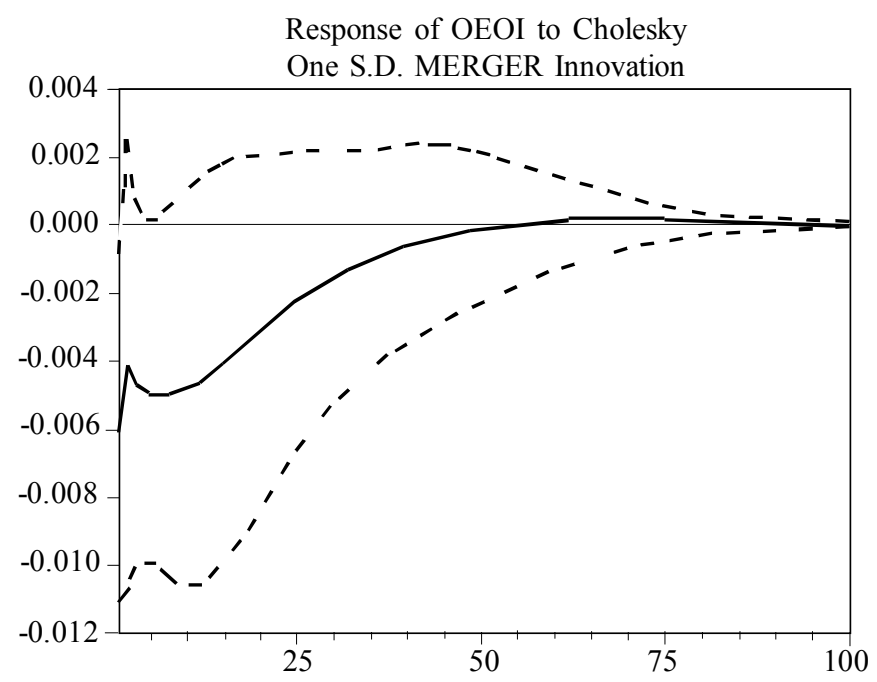


Lestari\&Arsyad-TheResponse ofPerformancetoMergerStrategyinIndonesian BankingIndustry

\section{Figure 12. IRF of Bank Permata's Profit Performance to Merger Shock}

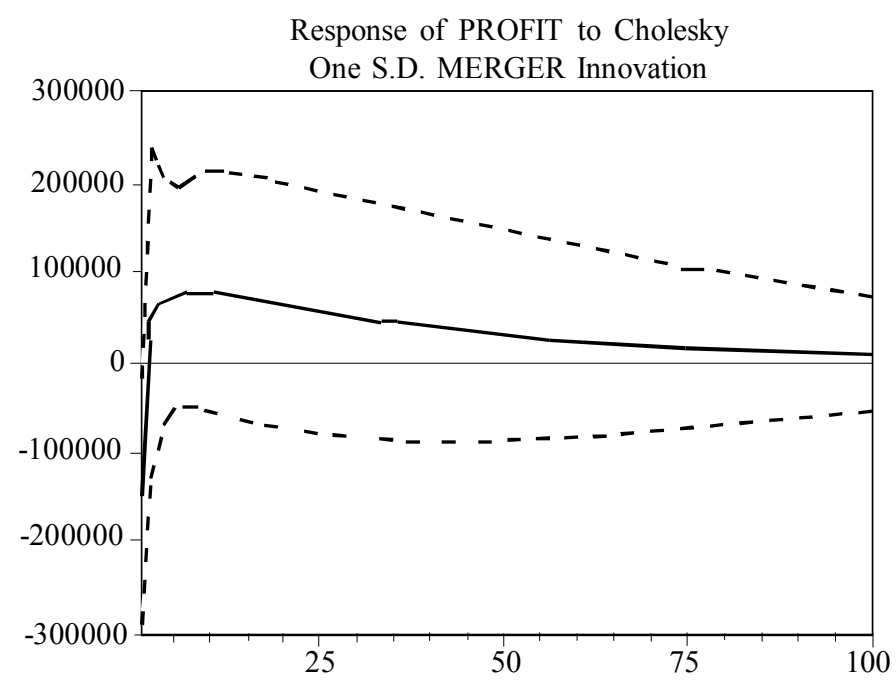

stable condition. With the response of performance always leading to efficiency direction, the length of time required to achieve the stable condition is expected to be much longer due to management innovations that always benefit or improve efficiency.

\section{d. IRF of Profit Performance}

The response of profit performance to merger shock for Bank Permata tends to provide an indicator that is consistent with the responses of other performances. The response of profit performance to one standard deviation in merger shock for this bank is shown in Figure 12. As can be observed in the figure, the profit variable never responds negatively to the merger shock. This is in accord with the response of other performance variables, where the credit/loan, OEOI, and spread variables always deliver the responses of efficiency.
Under these circumstances, it is reasonable that the profit never gives a negative response. Similar to OEOI, the profit variable also requires an extensive period to achieve the stable condition, which is more than 20 years. The conjecture is that it is caused by the managerial innovation processes that always improve efficiency.

\section{Discussion}

Based on the definition and concept shown in the Government Regulation No. 28/1999, the incorporation of Bank Mandiri is called a consolidation whereas the incorporations of Bank Danamon and Bank Permata are considered mergers. The analysis of structural breaks shows that the three merged banks, i.e., Bank Mandiri, Bank Danamon, and Bank Permata, have a vast array of patterns in responding the external shock of 1997-1998 crisis and 
the internal shock of mergers. The crisis shock seems to bring a similar shock that leads to structural breaks to the credit/loan variable of the three observed banks and to the OEOI variable for Bank Permata.

Different from the crisis shock, the merger shock does not lead to unified structural breaks to all performance variables of the three observed banks. The merger shock only causes structural breaks to the spread variables of Bank Mandiri and Bank Danamon. The other three variables, i.e., credit, OEOI, and profit, of the three banks do not experience structural breaks as a result of merger shock or crisis shock. Particularly for Bank Permata, the merger shock does not produce structural breaks to all observed variables.

Based on the patterns of structural breaks occurrences, when spread is used as the indicator of external efficiency, then the mergers of Bank Mandiri and Bank Danamon create a shock to the external efficiency, leading to structural breaks. Meanwhile, this phenomenon does not occur in the merger of Bank Permata since there is no structural break to all performance variables as a response to the merger.

The IRF analysis seems to substantiate the findings obtained from the structural break analysis. The IRF analysis, in general, finds that Bank Mandiri and Bank Danamon have a similar pattern. In their responses to the merger shock, the credit variables of Bank Mandiri and Bank Danamon decrease in the same direction, which is a continuously negative response until they reach stability. Meanwhile, the response of Bank Permata's credit variable to the merger shock is negative in the beginning and turns positive not long afterwards until it reaches stability. The periods into stability also differ; the credit stabilities for Bank Mandiri and Bank Danamon are attained 20 years after the merger shock, while Bank Permata could achieve the credit stability in less than 15 years.

The findings above indicate that there is a compelling difference in the pattern of the response of credit/loan variable to the merger shock. If associated with the character backgrounds of the banks involved in the mergers, there is an indication that the differences in characters of the banks result in the differences in responses. Bank Mandiri is the result of merger (consolidation) of four existent state banks, Bank Danamon is a merger of 11 banks, whereas Bank Permata is the result of a merger of five relatively small banks. One of the bank supervisory officials of Bank Indonesia, in an interview, states that the dynamics of mergers of large banks is much more complicated than that of relatively small banks. Therefore, one of the merger objectives, i.e., to improve bank efficiency, could be achieved, in general, more quickly by the merger of small banks. On this basis, Bank Mandiri and Bank Danamon have a similar response, which is a negative response of credit variable and a longer stability achievement compared to Bank Permata. On the contrary, the credit 
variable of Bank Permata shows a positive response, despite initially having a negative response. In managerial perspective, the merger of Bank Permata is inclined to strengthen its structure with less significant internal problems. Therefore, its management canimmediately and aggressively make loans, leading to stability in a much quicker process.

The same thing happens to the spread variable. For Bank Mandiri and Bank Danamon, the spread variable responds positively to the mergers, and never responds negatively until it reaches stability. The positive response means that there is an increase in spread in the post-merger period, and it signals an indicator of inefficiency in producing outputs (loans). This phenomenon does not occur in Bank Permata.

Another interesting finding is the response of profit variable. The response of profit for Bank Mandiri is initially negative (decreasing income), but after eight quarters (two years) it becomes positive. This pattern of response is slightly different from that for Bank Danamon. The response of Bank Danamon's profit never reaches the negative level, meaning that its reaction to the merger shock is always in the form of increasing profits.

If associated with the backgrounds of mergers, it appears that there are distinctions in the merger patterns of Bank Mandiri and Bank Danamon. The merger of Bank Mandiri is a consolidation; four banks are merged with no trace of existence. On the other hand, the unification of Bank Danamon is basically a merger; Bank Danamon still exists while the other banks are merged into it. It seems that this distinction leads to the differences in profit performance; merger generates profits more quickly than does consolidation. When these results are intertwined with organizational theory, it seems reasonable that organizations that get into the merger process are not as strong as those involved in the consolidation process. Thus, merger has indeed a better profit response.

For Bank Permata, the response of spread variable to the merger yields efficiency. Similarly, the responses of other variables, i.e., OEOI and profit, also show an indication of efficiency in the post-merger period. Based on these findings, we may conclude that the merger of small banks is more likely to obtain a response of efficiency than the merger and consolidation among large banks and the merger of many banks.

\section{Conclusions}

The structural break analysis shows that the 1997-1998 crisis has brought a shock to the three observed banks, particularly to the credit performance. However, mergers prevalent after the crisis do not necessarily lead to shocks to the entire three banks. The merger of Bank Permata even does not lead to shocks to all four performance measurements observed. Based on the observations on the three banks, it can be concluded that the merger of Bank Permata delivers a better perfor- 
Gadjah Mada InternationalJournal of Business,May-August2010, Vol.12,No.2

mance response than do the consolidation of Bank Mandiri and the merger of Bank Danamon. The merger of Bank Permata does not cause performance shocks that lead to structural breaks, whereas the consolidation of Bank Mandiri and the merger of Bank Danamon produce structural breaks, especially in the spread performance.

There are differences in the responses of performances to merger shocks for the three observed banks. The differences are very likely due to the differences in backgrounds and characters of the banks involved in the mergers. The IRF analysis shows that in order to return to the stable condition, the mergers of Bank Mandiri and Bank Danamon need a longer time than the time required by the merger of Bank Permata. This implies that the merger of small banks needs a relatively short period to return to the stable position. In addition, to be stable, the merger does not suffer from decreasing performance. In contrast, for large banks, the process toward stability takes a longer time and experiences a stage of performance decreases. For the merger of large banks, the mergers and acquisitions (retaining one existing bank) will deliver better performance responses than will the consolidations (no existing bank).

\section{References}

Allen, D., and Boobal-Batchelor. 2005. The role of post-crisis bank mergers in enhancing efficiency gains and benefits to the public in the context of developing economy: evidence from Malaysia. Working Paper. Edit Cowan University and Monash University.

Besanco, D., D. Dranove, M. Shanley, and S. Schaefer. 2004. Economics of Strategy ( ${ }^{\text {rd }}$ ed.). John Wiley \& Sons.

Calomiris, C. W., and T. Pornrojnangkool. 2005. Monopoly-creating bank consolidation? The merger of fleet and Bank Boston. NBER Working Paper Series No. 11351: 1-35.

Carletti,E., P.Hartmann, and S. Ongena. 2006. Theeconomic impact of merger control: What is special about banking?" Working Paper. European Central Bank.

Cerra, V., and S. C. Saxena. 2008. Growth dynamics: The myth of economic recovery. American Economic Review 98(1): 439-457

Dymski, G. A. 2002. The global bank merger wave: Implications for developing countries. Working Paper. Department of Economics, University of California.

Enders, W. 2004. Applied Econometrics Time Series ( $2^{\text {nd }}$ ed.). John Wiley \& Sons, Inc

Fulmer, R. M., and R. Gilkey. 1988. Blending corporate families: Management and organization development in post merger environment. The Academy of Management EXECUTIVE 11(4): 275-281 
Lestari\&Arsyad-TheResponse ofPerformancetoMergerStrategyinIndonesian BankingIndustry

Gorton, G., M. Kahl, and R. Rosen. 2005. Eat or be eaten: A theory of mergers and merger waves. Working Paper series (11364). The National Bureau of Economic Research.

Gujarati, D. N. 2003. Econometrics $\left(4^{\text {th }}\right.$ ed. $)$. McGraw-Hill, New York

Gujarati, D. N. andD. C. Porter. 2009. Econometrics (5 ${ }^{\text {th }}$ ed.). McGraw-Hill, New York

Koetter, M. 2005. Evaluating the German bank merger wave. Discussion Paper Series 2: Banking and Financial Studies (12). Deutsche Bundes Bank.

Koskela, E., and R. Stenbacka. 2000. Bank merger and the fragilityofloan market. Finnish Economic Papers 13 (1):3-18.

Kwiatkowski, D., P.C. Phillips, P. Schmidt, and Y. Shin. 1992. Testing the null hypothesis of stationarity against the alternative unit root. Journal of Econometrica 54: 159-178.

Mardanugraha, E. 2005. Efisiensi perbankan Indonesia dipelajari melalui fungsi biaya parametrik. Disertasi (unpublished).

Martin, S. 1994. Industrial Economics: Economic Analysis and Public Policy (2 ${ }^{\text {nd }}$ ed.). Macmillan Publishing Company, New York.

Perron, P., and P. C. B. Phillips. 1988. Testing for a unit root in time series regression. Biometrika 78(2): 335-346.

Perron, P. and T. J. Vogelsang, 1992. Nonstationarity and level shift with an application to purchasing power parity. Journal of Business and Economic Statistics 10: 301-320.

Perron, P. 1997. Further evidence on breaking trend functions in macroeconomics variables. Journal of Econometrics, Vol. 80,pp. 355-385

Samosir, A. P. 2003. Analisis kinerja Bank Mandiri setelah merger dan sebagai bank rekapitalisasi. Kajian Ekonomi dan Keuangan 7 (1).

Steensma, K. H., J. Q. Barden, C. Dhanaraj, M. Lyles, and L. Tihanyi. 2004. The influence of power, learning, and conflict on the internalization of international joint venture. Academy of Management Best Conference Paper: 1-6

Weber R. A., and C.F. Camerer. 2003. Cultural conflict and merger failure: An experimental approach. Management Science 49(4): 400-415.

Zivot, E., andD. W. Andrews. 1992. Further evidence on the great crash, the oil price shock, and the unit-root hypothesis. Journal of Business and Economic Statistics 10 (3): 251270. 